\title{
Preventing an Agunah Crisis in the Wake of the World Trade Center Disaster by Establishing Death Through Various Forms of Evidence
}

\author{
LEORA NATHAN ${ }^{\bullet}$
}

According to Jewish law, specific evidence confirming the death of a man is needed before his widow is able to remarry. In situations such as the attacks on the World Trade Center. where many victims could not be identified on the basis of their remains alone, evidence Iraditionally tendered to establish death was largely unavailable. This meant that a relaxation of some of the more stringent requirements for proof of death was required, and that some additional, novel categories of evidence had to be considered in establishing death. DNA fingerprinting and dental records are among the evidence that rabbis now consider to have some probative value in establishing death. In addition, telephone calls made and e-mails sent by the victims just prior to the altacks could be used as proof of presence within the towers. When considered in conjunction with assessments of the probability of escape from a given location within the towers, this evidence is given greater weight. The combination of traditional identification signs, processes and principles of proving death and the more recently acceptable methods has the effect of decreasing the waiting period before which a Jewish woman can conclude that her husband has perished, and can thus effectively bring some closure to a tragic circumstance.
Dans le droit juif, il faut des preuves confirmant la mort d'un homme avant que sa veuve ne puisse se remarier. Dans des cas comme les attaques contre le W'orld Trade Center ou un grand nombre de victimes n'a pu ètre identifié uniquement à partir des restes humains, les preuves traditionnelles n̈̈taient souvent pas disponibles. Il a donc fallu relaxer les exigences les plus strictes relatives aux preuves de décès et tenir compte des nouvelles catégories additionnelles de preuves. C'est ainsi que les rabbins reconnaissent maintenant les tests d'identification par le code génétique et les fiches dentaires comme identification de décès. En outre, les appels et les courriels des victimes juste avant les attaques ont servi $\dot{a}$ prouver qu'elles se trouvaient effectivement dans les tours. Si l'on considere les maigres chances de s'en tirer vivants. compte tenu de l'emplacement des tours, ces preuves prennent alors une plus grande importance. La combinaison des signes d'identification. des processus et des principes traditionnels prouvant le décès et les méthodes que l'on considère dorénavant comme acceptables a eu pour effet de réduire la periode d'attente avant qu'une femme juive ne puisse établir que son mari est effectivement mort et passer outre cette circonstance tragique.

\section{TABLE OF CONTENTS}

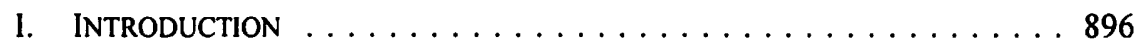

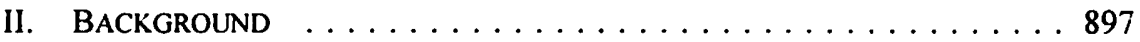

III. ANALYSIS . . . . . . . . . . . . . . . . . . . 898

A. SIMANIM MUVHAKIM - SIGNS THAT ARE

PERSONALly DESCRIPTIVE AND UNIQUE . . . . . . . . . . 899

B. WHEN NO SIMANIM MUVHAKIM (IDENTIFICATION

SIGNS) CAN BE FOUND — THE UMDANAH . . . . . . . . 904

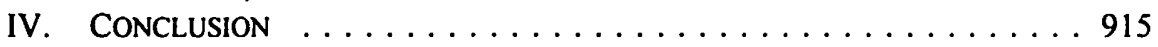

J.D. Candidate, Benjamin N. Cardozo School of Law, Yeshiva University, 2003; B.A. (cum laude) Barnard College, Columbia University. The author is Notes and Comments Editor of the Cardozo Women's Law Journal. The author wishes to thank Rabbi Michael Broyde of Emory University and the Beth Din of America for his guidance on this article. The author would also like to express her appreciation to her parents for their love and support and to Keyvan Ghaytanchi for his constant encouragement. 


\section{INTRODUCTION}

On the morning of 11 September 2001, two hijacked planes crashed into the World Trade Center. Both towers were ultimately consumed by the blaze and collapsed. During the course of the tragic event, thousands of parents, siblings, friends and coworkers were killed. In the wake of the tragedy, families are attempting to piece together their lives. Many New Yorkers have attended vigils, memorial ceremonies and religious services to remember and honour those who were killed. These services have the effect of providing healing and closure, especially in situations where there is no funeral or burial ceremony because a body cannot be found. For observant Jews who lost loved ones in the disaster, the opportunity for closure is less immediate. Before holding memorials for those observant Jews who died in the Trade Center, their death has to be proven and a dispensation given by a halakhic' authority. ${ }^{2}$ This process is of crucial importance to observant Jewish women because, without evidence of death, a woman may be forever prevented from remarrying within the tradition. She would become an agunah, ${ }^{3}$ a woman who may not remarry because her husband's whereabouts are unknown or his death unconfirmed. ${ }^{4}$ In order to prevent this situation

1 Halakhah is the term for Jewish law. Halakhic means "legal" in the sense that it complies with Jewish law. Thus, a halakhic authority is an authority in Jewish law.

Jewish law is decided by religious authorities who rely on two major bodies of law in making their decisions - the written law, commonly known as Scripture, and the oral law, which includes all of the Jewish law that is not explicitly set out in the written law. Both the oral law and the written law are considered equally authoritative. The oral law includes all of the various forms of halakhah throughout its evolution. See Menachem Alon et al., Jewish Law (Mishpat Ivri): Cases and Materials (1999) at 5, n. 2 [hereinafter Cases and Materials].

Throughout this article, references will be made to the Talmud. The Talmud is the foundation of the study of halakhah. It is composed of the Mishna and Gemara. The Mishna, developed around 200 C.E.. is the codification of the oral law. The Gemara, codified around 200 C.E. to 500 C.E.. is a collection of commentaries and discussions on the Mishna. See generally Cases and Materials at 7.

Most translations are my own. Where they exist, I have cited English translations. In citing the Talmud, I generally use Babylonian Talmud, I. Epstein, trans. (Soncino Press, 1961) [hereinafter Soncino]. The English translation of the Mishna is ordinarily that of Mis/ma Yebamot, N. Scherman \& M. Zlotowitz, eds. (Artscroll, 1984) [hereinafter Artscroll]. The Tractate Yebamot is a volume of the Talmud that embodies the laws governing particular marriage and dissolution of marriage questions. Many issues raised in this article are considered within that tractate. Tosafot is a twelfth- to thirteenth-century commentary on the Talmud compiled by scholars in France and Germany. It is cited here with regard to its gloss on Tractate Yebamot.

2 See generally J.H. Prager, "For Some Jews, 'Missing' is Not Presumed Dead" Wall Street Journal (1) October 2001) Bl [hereinafter Prager].

" The singular is agunah, literally "anchored" or "bound" wife; the plural is agunot (13 Menachem Alon, Jewish Law: History, Sources and Principles, B. Auerbach \& M.J. Sykes, trans. (1994) 522 [hereinafter Jewish Law]).

$+\quad$ The biblical prohibition of a married woman having sex with another man can be found in Leviticus 18:20: "and thou shalt not lie carnally with thy neighbor's wife, to defile thyself with her." See also Exodus 20:13: "Thou shalt not commit adultery." This injunction is directed at both men and women. The biblical prohibitions detail severe implications for wives of missing husbands. If a wife remarries and her first husband returns, she is considered an adulteress and must divorce both husbands. In addition, any children born to her second marriage will be considered illegitimate in the eyes of the law. By contrast, a man need not overcome as many legal hurdles in order to remarn: 
from arising, halakhic authorities have been searching strenuously for evidence that would "free" a woman from agunah status by establishing that her husband is dead. This article will analyze the various forms of evidence necessary to establish death in Jewish law for the purpose of freeing the agunah by discussing the approaches that scholars have used in their respons $a^{5}$ in the past 700 years to establish death in similar situations. ${ }^{6}$ These approaches can be applied to the Trade Center cases to certify a death according to religious law so that widows can begin the process of mourning, and eventually of healing.

\section{BACKGROUND}

In Jewish law, evidence tendered to establish death must have very high probative value $^{7}$ and must be offered by two male witnesses. ${ }^{8}$ The exacting requirements necessary to determine death are relaxed only for the purpose of preventing a woman from becoming an agunah. This flows from the principle that "he who releases a woman from becoming an agunah it is as if he has rebuilt the temple in Jerusalem" that is, it is very important to release a woman from becoming an agunah. ${ }^{9}$ In reliance on this principle, rabbis have continuously amended the Jewish laws of evidence and testimony ${ }^{10}$ throughout the past 2,000 years to make it easier to establish a missing husband's death." Thus, in deciding an agunah case today, an expert will consider,

Responsa (singular responsum), dating from as early as the eighth century C.E. until the present, constitute the case law of the Jewish legal system. See Cases and Materials, supra note 1 at 8. They are authoritative opinions given by halakhic authorities in all arcas of Jewish law in response to questions emanating from real situations. Contemporary authorities rely on the responsa literature as authority when ruling on cases brought before them. The literature has varying levels of authority depending on the scholarly standing of the author. Menachem Alon. former Deputy President of the Israeli Supreme Court, wrote the following regarding the authoritative weight of responsa literature in Jewish Law, supra note 3 at 976:

This quality of living law. which is the essence of every responsum. has endowed the law derived from responsa with special standing and force exceeding that of the law based on commentaries or novellae. Indeed, most halachic authorities rank rules derived from responsa even higher than those based on the codificatory literature, to the point of resolving an inconsistency between a code and a responsum in favor of the responsum.

Rabbi Ezra Batzri, Chief Justice of the rabbinical court in Jerusalem, addresses the importance of agunah legislation in his responsum. He cites the principle espoused by Maimonidies that in every generation it is incumbent upon rabbinic leaders of the community to enact legislation in order to prevent women from becoming agunahs. See E. Batzri. Tovat Haprat Mul Tovat Hatsibur. T'chumin (The Good of the Individual Versus the Greater Good) (1988) 63, 66. Maimonidies ("Rambam") (1135-1204) was a preeminent rabbinical scholar.

See, e.g., Part III A. below, on simanim muvhakim - signs that are personally descriptive and unique.

See Deuteronomy 19:15.

See Rabbi Isaac Herzog, Hechal Yitzchak, Even Haezer 117 (1960) citing Rabbi Yoel Sirkis ("the Bach") (Poland, seventeenth century) \$ 64. Rabbi Herzog was Chief Rabbi of Israel (1937-1959). See Jewish Law, supra note 3 at 528-29.

In biblical times, soldiers in King David's army gave their wives conditional divorces in case they did not return from battle. See Babylonian Talmud. Ketubot 9b, translated in Soncino, supra note 1. During the tannaitic period (the period of the Mishna, circa 70 C.E. to 220 C.E.) it was established that a woman may remarry on the basis of hearsay testimony, the testimony of a slave, woman, or servant [all of whom are generally not accepted as witnesses]. See Mishna, Yebamot 16:7, translated in Artscroll, supra note 1 at 357. 
among other categories, the probability of survival, circumstantial evidence, hearsay testimony, the testimony of women, the testimony of a single witness, and the testimony of people who talk about what happened in the disaster without realizing that they are testifying - none of which are normally acceptable in establishing death. ${ }^{12}$ In the case of the Trade Center in particular, where the number of people who will be identified by means other than direct identification is "unprecedented," 13 and where most victims will never be recovered, ${ }^{14}$ these allowances for relaxation of the usual rules of evidence are crucial.

\section{ANALYSIS}

There are two distinct categories of analysis that must be considered in identifying a person sufficiently to declare him or her dead. The first category establishes prima facie proof of a person's identity. It entails a consideration of the person's identifying signs, simanim muvhakim, personally descriptive signs that are so unique that people normally do not share them. ${ }^{15}$ Signs that are simanim muvhakim change with time, depending on how widespread they are in a given community or society. ${ }^{16}$ The fact that a person was known to have a nose-ring, for example, may have been a siman $m u v h a k^{17}$ in the early 1980 s, when few people wore nose rings. Today, however, when nose-ring wearers are widespread, the fact that a person was known to have worn one may not be determinative.

When identifying signs cannot be found, other methods must be relied on to assume death. ${ }^{18}$ The second category of analysis involves an assessment of what evidence is necessary to assume death in the absence of distinctive signs. ${ }^{19}$ In considering evidence within the second category, experts often conduct probability analyses using estimations of the chances of death given specific criteria. ${ }^{20}$ In each given case, experts will ask how much evidence is necessary or how much context of a situation must be known in order to assume that a person is dead.

See Mishna, Yebamot 16:7, ibid.

13 Rabbi Moshe Krupka of the Union of Orthodox Jewish Congregations of America, cited in R. Zoll, "'A Terrible Time' Identifying Jewish Victims" Jerusalem Post (23 September 2001) 3. "[New York City Mayor Rudolph] Giuliani has acknowledged that the 2,000 degree Fahrenheit fire caused by the explosions of the two planes and the implosion of the 110-story twin towers make it likely that some victims will never be recovered." Ibid. See Babylonian Talmud, Yebamot, 120b, translated in Soncino, supra note 1. University School of Law and member of the Beth Din (rabbinic tribunal) of America (7 February 2002).

Ix A rabbinic tribunal must rule on whether death can be assumed.

1") Supra note 16.

20 These considerations fall into the category known as umdanah - an "estimate." 


\section{A. Simanim MUVhaKIm - Signs that are Personally DESCRIPTIVE AND UNIQUE}

\section{THE DISCOVERY OF BODY PARTS}

The Mishna in Tractate Yebamot ${ }^{21}$ sets forth three conditions that must be satisfied in testimony regarding a death: ${ }^{22}$

1. Evidence [of identity] may be legally tendered only on [proof afforded by] the full face with the nose, though there were also marks on the man's body or clothing.

2. No evidence [of a man's death] may be tendered before his soul has departed; even though the witnesses may have seen him with his arteries cut or crucified or being devoured by a wild beast.

3. Evidence [of identification] may be tendered [by those] only [who saw the corpse] within three days $^{23}$ [after death]. ${ }^{24}$

Maimonidies writes in his codification of the law that if any of the above identifying factors is missing, even if there are identifying signs on the person's body and personal property, testimony regarding his death should not be offered. ${ }^{25}$ Rabbis Vidal ${ }^{26}$ and $\mathrm{Karo}^{27}$ differentiate among three types of signs: (a) signs that are not definitive; (b) signs that are definitive; and (c) signs that are extremely definitive. ${ }^{28}$ Signs that are not definitive are never effective modes of identification. ${ }^{29}$ Signs that are definitive are effective with regard to the identification of lost objects, as well as in other areas of monetary law. ${ }^{30}$ They are not effective with regard to the laws of marriage and divorce. $^{31}$ Signs that are extremely definitive can be relied upon in matters of marriage and divorce. ${ }^{32}$ Thus, if there is an extremely definitive sign on a corpse, it can be admitted as evidence to identify a body. ${ }^{33}$ In keeping with the severity of the prohibition of remarriage were a woman to remarry while her husband was still alive,

For a description of the contents of Tractate Yebamot, see supra note 1.

See Babylonian Talmud, Yebamot 120a, translated in Soncino, supra note 1.

The Mishna is concerned with the possibility that the body may have changed over time. For this reason, the criteria for identification are strict.

According to Rabbeinu Tam, these requirements apply only when the whole body is so destroyed that it cannot be recognized, and all that can be recognized is the face. If the body is whole, the testimony is accepted even without a face, forehead and nose, and even after the passage of three days. Rabbeinu Tam is Rabbi Yaakov Ben Meir (France. twelfth century). His lectures provided the basis of the Tosafot commentary, supra note !.

See Moses Maimonidies, Mishneh Torah, Laws of Divorce (Hilchol Gerushin) 13:21 (R. Eliyahu Touger trans., Moznaim 1995) at 239.

Rabbi Vidal (fourteenth century) of Tolosa, Spain, is known for his work the Maggid Mishneh.

Rabbi Yosef Karo (sixteenth century) of Spain, Turkey and the Land of Israel, wrote the Kessef Mishneh. Karo is best known for his authoritative work the Shulhan 'Arukh.

See Maimonidies, supra note 25 at $239, \mathrm{n} .48$.

lbid.

Ibid.

Ibid.

Ibid. at 239, n. 48.

Ibid. 
these rules of evidence are strict. ${ }^{34}$ The Talmud has therefore provided precautionary measures to ensure that the corpse is that of the missing husband.

\section{DENTAL RECORDS}

One category of evidence which the medical examiner, the US courts, ${ }^{35}$ and the rabbis agree is determinative proof of identity is dental records. Forensic odontology, the use of dentistry to solve problems in identification of humans, ${ }^{36}$ is the oldest of identification methods, predating both fingerprinting and DNA testing. Because each set of teeth has identifying marks that are unique to that set, dental records can be considered a siman muvhak for identification purposes. ${ }^{37}$ Additionally, experts involved in Trade Center dental identifications maintain highly accurate records of their work: dental records are reviewed four times by four forensic odontologists before they are released to families. ${ }^{38}$ Detailed matches to minute details of teeth, tooth fragments and dentures are made "with a degree of accuracy that has to be very high." ${ }^{39}$ As highly reliable evidence in their own right, combined with a low probability of error, dental records have been held to be highly probative evidence in determining death. ${ }^{40}$

\section{DNA FINGERPRINTING}

Nearly six months after 11 September, DNA fingerprinting was still being used regularly to identify victims of the Trade Center disaster. Although there is no consensus among rabbis regarding the probative value of DNA testing, American rabbis who are experts in the field have for the most part accepted DNA evidence for

This prohibition is severe because a child that is the product of an adulterous union is illegitimate

in the eyes of Jewish law.

is See Jennings v. Casscles, 568 F.2d 229 (2d Cir. 1977); United States v. Harris, 932 F.2d 1529 (5th Cir. 1991); United States v. Israel, No. 78-1146, 1979 U.S. App. LEXIS 16395 (7th Cir. 8 March 1979); Wallace v. Lockhart, 701 F.2d 719 (8th Cir. 1983); Stokes v. Singletary, 952 F.2d 1567 (1/th Cir. 1992) (federal courts regularly admit dental records as a dispositive method of identification of corpses).

Forensic odontologists identify people based upon their teeth, generally in cases of unrecognizable bodies or in major disasters. See H.C. Lee, "Forensic Science and the Law" (1993) 25 Conn. L. Rev. 1117.

7 See Beit Shmuel, Commentary on the Shulhan 'Arukh, Even Haezer 17:72, s.v. simanim muvhakim (noting that a siman muvhak is an unusual sign that is "found in one out of every thousand people ... a tooth is a siman muvhak, as is a crooked neck"). The commentary Beit Shmuel was written by Samuel B. Uri Phoebus (Poland, seventeenth century). It is considered a seminal commentary on Even Haezer, one of the four sections of the Shulhan 'Arukh. See 3 Menachem Alon, Jewish Law: History, Sources, Principles (Hamishpat Halvri), B. Auerbach \& M.J. Sykes, trans. (1994) at 1430 .

See Rabbi Gedalia Dov Schwartz, address at the Agunot and Mesuravot Get (Recalcitrant Husbands) Symposium, Congregation Kehilath Jeshurun (3 February 2002) [hereinafter Schwartz]. Rabbi Schwartz is a judge in a rabbinical tribunal that decided agunah questions in the wake of the Trade Center tragedy.

Hank Cutler, a dentist who volunteers his time identifying Trade Center victims by their dental records. See K.A. Graham, "Dentist Heeds Disasters' Call" Philadelphia Inquirer (20 December 2001).

*t Rabbi Dr. Moshe D. Tendler, address at the Agunot and Mesuravot Get (Recalcitrant Husbands) Symposium, Congregation Kehilath Jeshurun (3 February 2002) [hereinafter Tendler]. 
identification purposes. ${ }^{41}$ Normally, in performing DNA testing in a criminal case, a statistical analysis is conducted based on an extensive pool. ${ }^{42}$ In the case of the Trade Center, the pool is so small (under 3,000 people), that the probability of two people who died in the Trade Center having the same DNA is even slimmer than the probability that a criminal suspect shares the same DNA sequencing with someone within his or her own population. If the probability of two people sharing the same DNA is 1 in every 100,000 or 200,000 in a group, ${ }^{43}$ then DNA should fall into the category of a siman muvhak - a trait that is so unique that people are not likely to share it. The rabbis relied on this classification in one case, for instance, where a victim was declared dead based on DNA taken from the person's femur, where the only body part found was the victim's thigh. ${ }^{44}$ While authorities still differ as to the extent of probative value of DNA evidence, it often enters the calculus in weighing the probabilities of death.

Another factor that raises the probative value of DNA taken from Trade Center victims is that, unlike in a criminal case, where there is a fear that one side will slant the evidence to be beneficial toward its cause, ${ }^{45}$ there is no element of partisan prejudice in the process of identifying Trade Center victims. Also, today the use of DNA testing has become both increasingly sophisticated and widespread, so that both the secular ${ }^{46}$ and religious ${ }^{47}$ courts have revised their impressions of DNA testing from those formed during the earliest days of its use in the courtroom. The fact that today's DNA evidence is more probative than it was ten years ago, coupled with the inference that DNA evidence from Trade Center victims can be considered more probative than DNA evidence taken from the general population, enhances the

See Tendler, ibid. The Central Rabbinate, the authoritative religious legal body in Israel, has not accepted the use of DNA evidence for identification purposes, though they have accepted the use of fingerprints and dental records. The rabbinate will admit DNA evidence only when it is combined with other probative evidence.

42 Rebecca Sasser Peterson discusses the probability analysis conducted to determine DNA fingerprinting for the purpose of matching a perpetrator's DNA to the DNA of a defendant. She writes,

Once a match has been identified, the examiner must determine the statistical probability that this particular profile exists in a particular population. Generally this is done through the "product rule" in which the probability that one person in a particular population would display this banding pattern in one probe is multiplied by the probability that another person in the same population would display the same pattern for a second probe. In a criminal trial, the result might be explained by an expert in statistical probabilities as "the probability of selecting at random from the population an unrelated individual having a DNA profile matching the [defendant's] is approximately 1 in 200,000 in African Americans, 1 in 200.000 in Whites, and 1 in 100,000 in Hispanics.

R.S. Peterson, Note, "DNA Databases: When Fear Goes Too Far" 37 Am. Crim. L. Rev. 1219 at 1223, citing J.A. McKenna et al., Reference Guide on Forensic DNA Evidence in Reference Manual on Scientific Evidence (1994) at 273, 278.

Schwartz, supra note 38.

See J. Dwyer, P. Neufeld \& B. Scheck, Actual Innocence (New York: Doubleday, 2000) at 122. See generally Commonwealth v. Curnin, 565 N.E.2d 440 at 442 (1991) (determining that the value of the DNA testing conducted in that case did not need to be resolved because DNA testing was not generally established as acceptable). 
probabilities for successful victim identification. The rabbis can rely on these probabilities to determine the probative value that should be attributed to DNA fingerprinting analysis.

\section{Telephone Calls Made From the Trade Center $^{48}$}

In the approximately one hour and forty-five minutes between the first plane's collision into Tower One and the collapse of the buildings, many Trade Center victims contacted emergency personnel, friends and family via telephone. ${ }^{49}$ Telephone conversations between Trade Center victims and people outside the Trade Center can be considered simanim muvhakim of the person's presence in the buildings. Such conversations are unique and would not be confused with conversations with anyone else. At minimum, they establish the person's presence inside the buildings at the time of the crash..$^{50}$ They may even provide highly probative evidence of a person's death. Many victims stayed on the telephone throughout their ordeal, informing family members of the progression of fire and smoke up until their death. ${ }^{51}$ Thus, the rabbis attributed high probative value to testimony regarding these conversations, which became part of the analysis in many cases of missing victims.

\section{Swipe Card Records and E-malls as Prima Facie Proof of Presence}

There is a category of personal property such as wedding rings and wallets that one does not normally lend to another person. In deciding agunah cases, Jewish legal scholars assume as a matter of law that people do not lend property within that category. ${ }^{52}$ Thus, when a body is found with any of those personal effects, it is assumed that the body is that of the person who owned those effects. If personal effects within the category could be found in the Trade Center, or were sent from the Trade Center, that would constitute prima facie evidence that the missing person was in fact in the building when it collapsed.

In the past century, rabbinic authorities were challenged to find precedent that they could rely upon in ruling that wives whose husbands disappeared during the Holocaust, in wars, in vanished submarines, or at the hands of terrorists, among other situations, could remarry once they had given up hope of finding their husbands. Famous responsa were issued that applied various evidentiary approaches to establishing death. The most crucial element discussed in the responsa is the establishment of the presence of the person at the place and time of the disaster. This consideration will be examined in the context of the Trade Center disaster. See, e.g., H. Cooper, et al., "There Are No Words" Asian Wall Street Journal (12 October 2001) Al [hereinafter Cooper]; see also Prager, supra note 2.

so) See, e.g., Prager, ibid. (noting that volunteer ambulance corps Hatzolah kept the list of names of people who called the service).

si See, e.g., Cooper, supra note 49.

52 See Rabbi Gad Navon, Meniat Agunot Milchamah (Preventing the Agunot of War), 19 Noam 61, 91 (1976) citing Beit Shmuel, Commentary on the Shulhan 'Arukh, Even Haezer 17:69 [hereinafter Navon]. 
In his responsum Ahiezer, Rabbi Grodziensky ${ }^{53}$ ruled on the case of a woman whose husband had disappeared and was presumed dead. ${ }^{54}$ An unrecognizable corpse was found, clothed in a shirt with the missing man's passport inside it. Grodziensky held, citing authority, that the woman could remarry - that is, the man was determined to be her husband, based on the evidence of the passport in his shirt. Likewise, Rabbi Spektor held that personal letters written by a missing man's wife and found on the body of a corpse were determinative evidence that the corpse was that of the same missing man..$^{5 s}$ Spektor cited the Beit Shmuel, which maintains that because there is no purpose in borrowing someone else's personal letters, there is a rebuttable presumption (chazakah) that he is the same person to whom the letters were addressed. $^{56}$

\section{a. Swipe Cards}

Swipe cards may fall into the category of things that a person does not lend to anyone. ${ }^{57}$ This categorization is useful because, since the first attempted bombing of the World Trade Center in 1993, all Trade Center employees were issued swipe cards which they had to swipe through a detector in order to enter the building. ${ }^{58}$ Even guests to the building were issued temporary swipe cards. ${ }^{59}$ Thus, no one could enter the building without first swiping a card. If swipe cards were used exclusively by those to whom they were issued, then the records of who swiped in on the morning of 11 September should determine presence in the building at the time of the attack. ${ }^{60}$ However, there are several problems with this approach. One concern is that people may have lent their cards to others. Another consideration is that someone who swiped in early that morning could have later left the building. Though the probative value of the swipe-card records may be low because of these concerns, such records may help to swing the probabilities toward a final determination based on several pieces of evidence.

Rabbi Grodziensky (1863-1940) was the leading halakhic authority for Lithuanian Jewry. His responsa were published in the collection She 'elot Uteshuvot Ahiezer (Vilna, 1922). See Navon, supra note 51, at 89-90, citing 3 Rabbi Chaim Ozer Grodziensky, Ahiezer (1946). See Navon, ibid. at 91 , citing Spektor (noting that "the concern that he may have thrown the letters away and the dead person who had them in his pocket picked them up - the chances of this happening are 'rachok she-ein lehaaloto al hadaat' - so distant that we should not even consider it"). R. Yitzchak Elchanan Spektor was one of the leading halakhic authorities of the last century. He is the author of Ein Yitzchak, a collection of responsa. See Navon, ibid. This presumption is made only with those things that a person does not lend out. i.e., a wedding band or wallet. See Rabbi Mordechai Willig. address at Congregation Ohab Zedek (30 October 2001) [hereinafter Willig].

s* Ibid.

sy Ibid.

w Ibid. (suggesting that Cantor Fitzgerald's swipe-card records may yet be retrieved since they were held off-site). 
b. E-mails

Many of those who perished in the collapse had been at their desks long before the attack. Some sent e-mails as early as several hours before the first plane hit the buildings. ${ }^{61}$ If it could be established with relative certainty that someone had sent an e-mail from his office, that he was in fact the one who sent the e-mail, and that the time and date of the e-mail were correct, then the person's presence at work could be established. E-mails written from a work account fall into the category of property that one would not lend out, in that the author of an e-mail from a work account is normally the person in whose name the account is registered. ${ }^{62}$ Also, because e-mail accuracy in a work environment, especially in a financial corporation, is important, the time and date was likely accurate. In addition, if someone set out for his office in the morning and later sent an e-mail from an office account regarding work-related business, the probability that the e-mail was in fact written from his office is high. Thus, e-mails sent from the Trade Center should be categorized as personal property that is not lent out and therefore admissible evidence of presence in the Trade Center.

\section{B. When No Simanim MUVhakim (Identification Signs) Can Be Found}

\section{THE UPPER FloORS CAN BE LIKENED to A FURNACE}

The upper floors of the Trade Center can be viewed in terms of the talmudic furnace paradigm, where one who falls into a furnace can be declared dead. ${ }^{63}$ This stipulation is provided because of the certainty that one who falls into a furnace will necessarily die.

In the Trade Center, there was virtually no chance of escape for anyone above the point of impact of the airplanes. ${ }^{64}$ Numerous people on those floors were trapped in an inferno of flames and smoke, from the moment of attack up until the building's collapse. ${ }^{65}$ In addition, the 2,000-degree temperature made it impossible for anyone trapped in the flames to survive. ${ }^{66}$ Thus, the predicament of those on the upper floors complies with even the strictest interpretation of the furnace category, which holds that the classification can be applied only where the furnace is so deep that a person cannot

\section{Ibid.}

This is important in a work environment, where many companies have a regular practice of reading employees' e-mails. This practice discourages employees from sharing e-mail accounts. See "Big Brother is Reading Your Emails" Irish Times (7 September 2000) 13.

See Babylonian Talmud, Yebamot $121 \mathrm{~b}$, translated in Soncino, supra note 1 ("our rabbis taught [if a man] fell into a burning furnace, evidence may be legally tendered concerning him [to prove his death]").

The first plane hit the north tower at about the 96th floor. The impact ignited more than 20,000 gallons of jet fuel and exposed the steel to temperatures of 2,000 degrees Fahrenheit. The second plane hit the south tower at about floors 80-86, also setting the building on fire at a temperature of 2,000 degrees. See Avery Comarow et al., "Anatomy of a Collapse" U.S. News \& World Report (24 September 2001) at 16.

is See E.T. Pound et al., "Under Siege" U.S. News \& World Report (24 September 2001) 6.

(ki) Ibid. at 16 
emerge from it. ${ }^{67}$ The furnace paradigm is perhaps the most often applied category in the Trade Center cases, since all that has to be proven is presence on the upper floors at the time of impact. ${ }^{68}$ This category was in fact relied upon by rabbis in at least one case of a man who was trapped on the 97 th floor. ${ }^{69}$ His family was permitted to begin shiva - the ritual mourning period - as early as 20 September $2001 .^{70}$

\section{BOUNDLESS WATER VERSUS WATER THAT IS SURROUNDED BY LAND}

The Tractate Yebamot states that, if a man falls into water that has a visible end, his wife is permitted to remarry, but if the water has no visible end, his wife is forbidden from remarrying. ${ }^{71}$ The reasoning for this is that, in the case of water that has no visible end - for example, an ocean - it is possible that the victim may have surfaced undetected on another shore. As long as a witness did not have the opportunity to see that the person drowned then and there, the victim cannot be declared dead. On the other hand, the case of the water that has a visible end (for example, a lake) illustrates a situation where it is possible to know with certainty whether or not the person perished. With water that has a visible end, a witness has a view of or access to any shores to which the victim may have escaped or been rescued. The witness could investigate by inquiring along the shore whether anyone had seen the victim. Also, having waited long enough along the shore that the drowning victim must have perished, the witness could personally ascertain that he did not survive. The distinction between the two categories hinges on the opportunity of the victim to escape. It is crucial for the purpose of allowing a wife to remarry to establish that her husband definitely perished - that, given the circumstances, he could not have survived undetected.

The concept of boundless water versus water that is surrounded by land is of pivotal importance to those who must determine a husband's death for the purpose of his widow's remarriage. Whether a husband's situation in the Trade Center can be classified in one category or the other may determine whether or not he can be declared dead. ${ }^{72}$ Cases where people were trapped on the upper floors above the point of impact are simpler, since it is known that they had no means of escape. ${ }^{73}$ Those cases can be likened to a person who drowns in a pond, where it is obvious to an observer that the victim could not have emerged alive. Those who worked on lower floors and whose arrival at work that day was never established, or who were not seen or heard from at various points during the morning of 11 September, may fall into the category of

See C. Mechokek, "Commentary on the Shulhan "Arukh" Even Haezer 17:57; see also B. Shmuel, "Commentary on the Shulhan "Arukh" Even Haezer 17:92.

According to Willig, supra note 57, the people on the airplanes that hit the Trade Center fall into this category because their presence on the airplane was established by the plane's passenger list. See Cooper, supra note 49.

Ibid.

See Babylonian Talmud, Yebamot 121a, translated in Soncino, supra note 1.

See Rabbi Shlomo Goren, Ha-tarat Ha-Agunot Shel Tzevet Ha-tzolelet "Dakar" (A Dispensation for Agunot of the Crew of the Submarine "Dakar"), 2 Meorot 14, 59-61 (1981) [hereinafter Goren, citing M. Sofer, "Responsa of the Chatam Sofer" Even Haezer, s. 65].

See generally Cooper, supra note 49 . 
boundless water. Like the person in a boundless body of water who may have grabbed onto a plank of wood and floated to safety on a far shore without being detected, ${ }^{74}$ a person in the Trade Center may have escaped unseen, or may have simply never arrived at work that morning. In those cases, death cannot be determined with sufficient certainty to allow a widow to remarry. For this reason, rabbis have strenuously collected evidence that would place the men in question within the Trade Center at the time of the crash and collapse in order to classify them as having perished in a body of "water that has a visible end" and allow their wives to remarry.

Rabbi Feinstein 75 addressed the issue of "boundless water" in his responsa "Iggrot Moshe" ("Correspondence of Moses"), which dealt with spouses who disappeared during the Holocaust. ${ }^{76}$ In the responsa, Feinstein considered the legislative intent behind the "boundless water" stricture. ${ }^{71} \mathrm{He}$ noted that the majority opinion is that in the case of a man who falls into "boundless water," a wife is permitted to remarry. ${ }^{78}$ The rabbis of the Talmud, however, did not follow the majority opinion because of the severity of the issue. They were concerned with the possible result of a woman remarrying on the basis of erroneous information that her husband is dead. ${ }^{79}$ Feinstein maintained that the rabbis intended this legislation to apply to cases that involve the disappearance of one person. The legislation was not intended to apply to doubt concerning the disappearance of many people, as in the case of those who disappeared during the Holocaust. In the case of many disappearances, Feinstein held that the legislation adopted in the Talmud should be distinguished and the majority opinion in favour of leniency followed ${ }^{80}$ In this respect, the Trade Center cases, which entail the disappearance of thousands of people, are comparable to the Holocaust-era missingspouse cases, and therefore should also be distinguished from those cases for which it was held that the spouses of the missing may not remarry. The majority opinion allowing a woman to remarry even in the case of "boundless water" should be followed in the Trade Center cases, just as it was in the Holocaust-era cases.

\section{THE PRINCIPLE OF AVAD ZICHRO - DisCHARGED FROM MEMORY}

Rabbi Eliezer of Verdun (thirteenth century) authored a responsum in which he ruled on the case of a widow whose husband had evidently drowned in a shipwreck seven years earlier. ${ }^{81}$ His body was never retrieved, but his personal belongings had washed up on shore. There were no known survivors of the wreck. In ruling that the widow

74 See Babylonian Talmud, Yebamot, 121a, translated in Soncino, supra note 1.

75 Rabbi Moses Feinstein (1895-1986) was head of the school Yeshivat Tiferet Yerushalayim in New York from 1936 to 1986 . He was universally recognized as one of the outstanding Torah scholars of his time.

76 M. Feinstein, Iggrot Moshe (Correspondence of Moses) Even Haezer (Balshon, 1961) [hereinafter Feinstein].

lbid. at 103.

lbid.

Feinstein, supra note 76 at 103.

lbid.

Rabbi Eliezer b. Shmuel, Avad Zichro: the Responsum of Rabbi Eliezer of Verdun, (c. 1221) reprinted in Rabbi Isaac Herzog, Hechal Yitzchak, Even Haezer $\$ 1,113$ (1960). 
could remarry, Eliezer applied a two-pronged test. ${ }^{82}$ First, since the husband had not returned for so many years, had had no marital problems, ${ }^{83}$ and had left young children behind, the suspicion that he may have abandoned his family was unlikely. This illustrates the principle of avad zichro, or "discharged from memory." 84 Second, the facts that there were no known survivors of the disaster and that his personal belongings washed up on shore provide strong circumstantial evidence that he was dead. Eliezer concluded that the satisfaction of both prongs - (1) he had no reason to leave home, so that if he had survived he would have contacted his family by now (avad zichro); and (2) strong circumstantial evidence of death - allow for a ruling that he is dead for the purpose of the wife's remarriage.

More recently, this approach has been applied to cases where the circumstantial evidence is even weaker than that considered by Eliezer. In deciding whether a woman whose husband was abducted by terrorists could be declared a widow for insurance purposes in Israel, Rabbi Dichovsky ${ }^{85}$ held that, though there was only hearsay evidence that the woman's husband was dead, only one informed opinion that he was killed, and no witnesses to the abduction, the woman could receive widow's benefits. ${ }^{86}$ Dichovsky applied the two-pronged test. The husband had not contacted anyone in many years, satisfying the first prong of the test. Dichovsky satisfied the second prong by categorizing the evidence of death as extensive circumstantial evidence. He wrote that falling into the hands of terrorists is "like falling into a lion's den," in that terrorists' treatment of Israeli prisoners is notorious. Even though normally the evidence in this case would not be sufficient to establish death, there is strong circumstantial evidence that the man was abducted by terrorists, and that evidence is sufficient in this case.

Rabbi Yose $\mathrm{f}^{87}$ authored a responsum regarding soldiers missing in action during the 1973 Yom Kippur War, when approximately 1,000 women lost their husbands in battle. ${ }^{88}$ Yosef analyzed the different categories of attainable evidence and found that the disc (or "dog-tag") worn around a soldier's neck had the most probative value since the disc falls into the category of property that a soldier would not lend to anyone. ${ }^{89}$ Also dispositive were discs or documents found in a soldier's pocket, since soldiers are

Ibid. The source for this approach is Rabbi Ashi's comments in Babylonian Talmud, Yebamot 121a, translated in Soncino, supra note 1.

See Mishna, Yebamot, 15:1, translated in Artscroll, supra note 1.

The concept of avad zichro is derived from the Mishna in Yebamot, where it states "if a man fell into the water, whether it had a [visable] end or not, his wife is forbidden [to marry again]." See Babylonian Talmud, Yebamot 121a, translated in Soncino, supra note 1.

Rabbi Shlomo Dichovsky is a judge in the highest rabbinical tribunal of Jerusalem.

See Shlomo Dichovsky, Bi-ishah Asher Ba'alah Nehtaf Bi-yiday Michablim Ve-ikvotav Lo Nodau, HaDarom (In re the Woman Whose Husband Was Abducted by Terrorists and His Whereabouts are Unknown) (1980) 155, 158.

Obadiah Yosef is the former Sephardic Chief Rabbi of Israel.

Rabbi Obadiah Yosef, Hatarat Agunot Shel Milchemet Yom Hakipurim. Torah She B'al Pe (Dispensation of Agunot of the Yom Kippur War) (1975) 11 at 20 [hereinafter Yosef].

Ibid. at 12-13 (Yosef observed that because the discs are used for identification in case of emergency, soldiers do not lend them to others). 
unlikely to lend out their uniforms. ${ }^{90} \mathrm{He}$ also found identifications via photographs after death ${ }^{91}$ and identification of fingerprints and dental records ${ }^{92}$ to be dispositive evidence.

Yosef was able to rule this way in large part because the determination of the solders' deaths satisfied the biblical law, and thus his ruling would only involve a question of rabbinic law. ${ }^{93}$ There is a two-pronged basis for the satisfaction of the biblical category of the determination of death. First, the men did in fact go to war but never returned. Second, their disappearance falls into the category of avad zichro. These two prongs provide sufficient circumstantial evidence of their death to satisfy the biblical prohibition.

For the purposes of the Trade Center determination, a parallel two-pronged analysis places those whose presence in the buildings could be established with certainty outside the boundaries of the biblical prohibition. The soldier who never returns from battle can be likened to a person who entered the Trade Center and was never heard from again. That prong, combined with avad zichro, should determine the victim'sdeath sufficiently to satisfy the biblical prohibition. Thus, as long as presence in the Trade Center can be established, the potential for transgressing a biblical prohibition can be avoided, and rabbis can feel freer to rule on the evidence.

In recent years, with the development of improved communication technologies such that citizens of disparate nations inhabit one "global village," the concept of avad zichro has been strengthened. Today, the use of newspapers, telephones, cellular phones, faxes and e-mail would enable even a person stranded far from home to contact his or her loved ones. ${ }^{94}$ This ease of communication has narrowed the time period before which it can be declared that all hope is lost and a woman may remarry. Whereas at one time rabbis held that a woman would have to wait three or even seven years after her husband's disappearance to remarry, today rabbis have held that she should wait only one year. ${ }^{95}$

A principal reason that the determination of death is so important in Jewish law is because the period of mourning cannot begin until it is determined by rabbinic authorities that the person is actually dead. For many who lost loved ones in the Trade Center tragedy, who could not say goodbye to their deceased relatives, or, more often, could not hold a burial ceremony for them (since bodies could not be found), the period of mourning was a crucial opportunity for closure. Thus, it was important for rabbis to

x) $\quad$ lbid.

$91 \quad$ lbid. at 20.

$92 \quad$ lbid. at 22.

93

Transgression of a rabbinically ordained law is less severe than transgression of a biblical precept, which is binding authority.

See Goren, supra note 72 at 15 , citing Sofer, ibid., s. 45 .

According to Rabbi Eliezer of Verdun, because the timing of avad zichro will depend on the circumstances in each situation, it is up to the experts of the time to decide when it has occurred. When in the 1970s an Israeli submarine disappeared off of the Egyptian coast, Rabbi Goren, then Chief Rabbi of Israel, held that a twelve-month period was appropriate. Goren, ibid. at 62 . 
expedite the process to enable families to mourn. ${ }^{96}$ In the case of the Trade Center, rabbis considered the various forms of evidence discussed in order to declare a person dead well before the close of a one-year period. That is, they did not have to resort to the avad zichro analysis in order to conclude that the widow could remarry. The avad zichro analysis will likely apply to those cases where there is less evidence of death, those where the husband was not seen in the building before it collapsed, or where he made no phone or e-mail contact, for example. Avad zichro will likely be applied, if at all, to those cases where a person's death has yet to be determined.

\section{WITNESSES}

According to Jewish law, at least two witnesses must testify to establish any material fact. ${ }^{97}$ Thus, two witnesses must testify to a husband's death in order for a wife to be permitted to remarry. Early on, legislation was enacted to permit a woman to remarry based on the testimony of only one witness, ${ }^{98}$ and even based on the wife's testimony alone. ${ }^{99}$ Other forms of testimony that from a very early period have been acceptable in agunah cases include hearsay testimony and testimony of a slave or a maidservant, ${ }^{100}$ both of which are ordinarily not admissible to establish a material fact.

The laws of evidence have continually been relaxed in agunah cases in recognition of the difficulty of establishing a person's death, particularly in times of war or upheaval. ${ }^{101}$ Maimonidies elucidates the special legislative amendments made specifically for agunah cases:

Do not wonder at the fact that our Sages discharged the prohibition [against a married woman's remarriage], which is considered a very severe matter, on the basis of the testimony of a woman, a servant or a maidservant, statements made ... in the course of conversation, a written statement or [testimony] that was not investigated by the ordinary process of interrogation, as we have explained.

See generally Prager, supra note 2.

See Deuteronomy 19:15. See also Babylonian Talmud, Gittin 2b, translated in Soncino. supra note I.

See Mishna, Yebamot 16:7, translated in Artscroll, ibid. The history of this legislation can be found in Jewish Law, supra note 3 at 522-25.

See Mishna, Yebamot 15:1-2, translated in Artscroll, ibid. The history of this legislation can be found in Jewish Law, ibid. at 522-25.

See Mishna, Yebamot 16:7, translated in Artscroll, ibid. See also Babylonian Talmud, Yebamot $87 \mathrm{~b}$, transiated in Soncino, ibid. ("the practice was adopted of allowing a marriage on the evidence of one witness reporting another single witness (hearsay), and of a woman reporting another woman, and of a woman reporting a bondman or a bondwoman; from which it is obvious that one witness is trusted"). Shulhan 'Arukh, Even Haezer. 17:3 ("a woman whose husband sails off and a witness testifies that he died - even if a slave or a maidservant or a relative witnessed the event [who are normally not permitted to testify] they may testify. Even hearsay testimony is admissible"); Shulhan 'Arukh, Even Haezer, 17:56 ("it makes no difference if she [re]married based on the tesimony of one witness or two witnesses").

See Jewish Law, supra note 3 at 525. 
[These leniencies were instituted] because the Torah requires only testimony of two witnesses, and all the other details of the laws of witnesses, with regard to matters that cannot be verified definitively except via witnesses and their testimony - e.g., that one person killed another, or that one person lent money to another. When, by contrast, the matter may be verified definitively without the testimony of a witness, and the witness cannot justify [his statements] if they are not true - e.g., when one testifies that a person died, the Torah did not necessitate [that the requirements of formal testimony be met in these instances]. For it is unlikely that a witness will testify falsely.

For this reason, our Sages [extended] the leniency with regard to this matter and accepted the testimony of a single witness that is based on the testimony of a maidservant, testimony from a written document, and [testimony] that was not investigated by the ordinary process of interrogation. [These leniencies were accepted] so that the daughters of Israel will not be forced to remain unmarried. ${ }^{102}$

In observance of this precedent of leniency in the field of agunah law, rabbis who decided Trade Center agunah cases considered many forms of evidence that would not normally be admissible. Testimony of both male and female coworkers, hearsay testimony and other forms discussed above were admitted to free women from agunah status. $^{103}$

While testimony and evidence to establish death are relaxed in agunah cases, there are still some unconditional criteria that must be met. The testimony must be reliable, both in that the witness must not have incentive to lie, and in that the witness's testimony may not rely on a conjecture based on a presumption of facts. For example, the Talmud in Yebamot states that if a woman reports that there is a war in the land in which she and her husband were travelling, and that her husband was killed in war, her testimony is not accepted. ${ }^{104}$ The reason given for this rule is that, though her husband did in fact disappear, she is perhaps guessing on the basis of probability that, since there is a war, he must have been killed in it. The Talmud here is expressing a concern that the wife's conclusion regarding her husband's death could be based on fantasy or conjecture. It discounts her testimony not because she is female, ${ }^{105}$ but because she has incentive to conclude that her husband is dead even if she does not know this with certainty. During a long period in history, when only marriage offered the benefits of financial support as well as social acceptance, single women suffered. Since it was in a woman's best interest to remarry as soon as possible, she could not be relied upon to give testimony regarding her husband's death. Spektor, in ruling on agunah cases, held that one witness is believed when that witness's testimony is reliable - that is, when there is no concern that he or she is guessing. ${ }^{106}$ In other words, the concern is that the witness testifies based on a guess. Where the witness, male or female, has no incentive to presume or conclude irresponsibly, that person's testimony is acceptable.

106 See S.B. Freehof, The Responsa Literature and A Treasury of Responsa (1973) at 290-91. 
In the Trade Center cases, the question of whether a woman merely speculates that her husband is dead is of concern, since in some cases husbands left home on the morning of 11 September and were simply never heard from again. For this reason, it is not enough, for example, that a woman presents her husband's business card stating that he worked on the 103rd floor of the Trade Center to conclude that he must have perished in the disaster. ${ }^{107}$ In the days and weeks following the tragedy, rabbis collected the most reliable testimony and most probative evidence they could find in order to avoid a ruling based on the kind of speculative presumptions enjoined by the Talmud. ${ }^{108}$ In keeping with the legislative intent behind the talmudic laws, the most reliable testimony, no matter who the witness, is admitted in order to prevent women from becoming agunot.

\section{SPEKTOR'S CONCEPT OF THE “DOUBLE MAJORITY”}

Spektor is credited with the explication and application of the concept of the "double majority" to agunah cases. A double majority comprises two "principles of the majority," two scenarios each of which is highly probable in its own right, which raised together, constitute an exceedingly probative evidentiary finding. Spektor held that the rabbis decreed the law of "boundless water" applies when only one legal "principle of the majority" (highly probable scenario) indicates that the husband is dead. ${ }^{109}$ However, when there are two different "principles of majority" that he is dead, there is no rabbinic ordinance enjoining the woman from remarrying. Once there is a "double majority," the husband can be declared dead and the wife permitted to remarry.

Spektor gives several examples of the "double majority." 110 A man fell into a stream, was hit by a large piece of lumber and disappeared into rushing water. Spektor held that this scenario constituted a "double majority" and thus permitted the man's wife to remarry for two reasons: first, the majority of people hit by lumber in such situations die; and second, the majority of people are dead if they do not surface after drowning. In another case, a boat caught fire and sank in the ocean. "I Experts testified that it was almost impossible that anyone was saved from the fire. Spektor held that, "despite the stringency of the state of marriage and the rabbinic interdiction of 'water that has no visible end,' perhaps when there is a 'double majority' this edict does not apply."112 The double majority is as follows: (1) it can be assumed that a majority of the passengers died as a result of the fire; and (2) the majority of those lost in the ocean die.

In another case brought before him, Spektor utilized the principle of avad zichro, "discharged from memory," as one majority. Two agunot came to Spektor, whose

See Willig, supra note 57.

B. Kladko, "Attacks Made Sleuths of Some Rabbis; Clues Sought to Support Death Certificates" The Record (Bergen County) (27 November 2001) 1.

A. Rakeffet-Rothkoff, "Rabbi Yitschak Elchanan Spektor of Kovno: Spokesman for Agunot" (1995) 29 Tradition 5 at 12 [hereinafter Rakeffet-Rothkoff].

lbid. at 13.

Ibid.

lbid. 
husbands' boat had sunk as it set sail from London. There were no survivors. Each couple's relationship had been peaceful and loving and therefore there was no reason to think that the men had purposely abandoned their wives. Spektor held there was a double majority here: (1) the majority of those lost at sea die; and (2) the majority of men that survive a shipwreck would contact their wives within a sensible amount of time (the "discharged from memory" principle). ${ }^{113}$

Spektor also considered the effect of modern technology on a person's ability to contact his or her family following a disastrous situation. Spektor cites Rabbi Ashi, a rabbi in the Talmud, who declared that "the rabbinic decree of "water which has no visible end' applies only to an ordinary person but not to a rabbinic scholar, because if the latter were rescued, everyone would hear about it" (since he's a famous person). ${ }^{114}$ Today, with mass communication, this is true for everyone and not just scholars. Anyone could notify loved ones within a short amount of time to relate that he or she was rescued. This principle works as a second majority. In this case, the husbands wrote warm letters to their families. They would have contacted their families if they had survived. According to Spektor, the fact that they did not notify their families is the greatest certification of their deaths, since there was no reason for them not to. Thus, avad zichro constitutes the second majority in this case.

The principle of the double majority can be applied to Trade Center death cases in numerous ways. One can assert a "principle of the majority" that most of those who were above the points of impact did not survive, or that most of those who were in the Trade Center at the time that the buildings collapsed did not survive. It can even be assumed that in a given person's daily routine, a majority of the time that the person leaves home for work, that person does in fact go to work. Avad zichro can be employed as a double majority: the majority of men who survived the Trade Center disaster would have contacted their wives. If a man did not contact his wife, he likely did not survive. The validity of each principle must be weighed by rabbinic authorities, and then admitted along with other probative evidence for a final determination of the plausibility of death.

6.

\section{LIKELIHOOD OF SURVIVAL}

In deciding agunah cases, rabbinic authorities consider every contributing factor that could increase the chances that a man did not survive. Aside from hard evidence, the rabbis perform probability calculations. ${ }^{115}$ In a responsum dealing with agunot whose husbands disappeared during the Holocaust, Rabbi Weiss describes the situation in the concentration camps vividly in order to show how unlikely it would be for a person to

$113 \quad$ Ibid. at 14.

114 Babylonian Talmud, Yebamot 121a, translated in Soncino, supra note 1.

115 Where no simanim muvhakim (distinctive signs) can be found, the Talmud relies on probability to assume death. Many contemporary authorities have followed this course by relying on similar analyses in their responsa. 
survive. ${ }^{116}$ Rabbi Herzog divides his analysis based on where in the camps the victims were last seen, since, for example, prisoners who were relegated to work posts had a greater chance of survival than those who were chosen for immediate death. ${ }^{17}$ Rabbi Goren uses a statistical analysis based on reports of nine missing submarines between the years 1947 and 1968 in issuing his dispensation for the 99 Israeli sailors who disappeared with the submarine "Dakar."118 While probability does not replace hard evidence, it is a strong component of any missing-in-action agunah analysis.

In assessing cases of people who died in the Trade Center, rabbinical analysis depends largely on calculations of likelihood of survival. ${ }^{119}$ One member of the Beth Din of America ${ }^{120}$ described a case where the court conducted an extensive investigation in order to increase the probability that a husband had been in his office in the Trade Center when the first plane hit the buildings. ${ }^{121}$ The man's credit card bill indicated that he had bought a MetroCard ${ }^{122}$ on the morning of 11 September. The rabbis contacted the Metropolitan Transit Association to determine when the man swiped his MetroCard to enter the subway station, which train he would have taken given the time he entered the station, and what time that subway arrived at the Trade Center station. The rabbis then calculated how long it would have taken the man to walk to the Trade Center and arrive in his office. According to their calculations, he would have arrived at approximately 8:43 A.M., three minutes before the first plane crashed into Tower One. This calculation shifted the probabilities heavily toward a determination of death. Each case considered by a rabbinical court is analyzed with a similar approach. When a body cannot be found, the rabbis must create a sketch of circumstantial evidence that will permit them to determine that the chances of survival are slim. In such cases, this probability analysis may be the sole assessment used to assume death.

\section{RELIANCE UPON THE City's DEATH CERTIFICATES}

The Talmud states that all documents which are accepted in secular courts can be entered into evidence in Jewish courts, except for writs of divorce and emancipation. ${ }^{123}$ Thus, death certificates officially recorded by a secular court are

See Rabbi I.J. Weiss, Minchat Yitzhak, \$1-5 translated in Solomon B. Freehof, The Responsa Literature and A Treasury of Responsa (1973) at 300-303. Rabbi Weiss (1902-1989) was head of the rabbinical tribunal in Manchester, England (1949-1969) and acted as Chief Justice of the Eidah Chareidit rabbinical tribunal in Jerusalem (1969-1989).

Rabbi Isaac Herzog. Responsa Hechal Yitzchak, Even Haezer 160 (1960) at 117.39 [hereinafter Herzog].

See Goren, supra note 72 at $56-57$.

See Feinstein, supra note 76.

The Beth Din of America is a rabbinical tribunal that was founded by and is affiliated with the Rabbinical Council of America (RCA). It is sponsored by the Union of Orthodox Jewish Congregations of America.

See Rabbi Jonathan Reiss, address at West Side Institutional Synagogue (10 February 2002) [hereinafter Reiss].

A MetroCard is a fare card that is purchased from a teller or machine in the subway station. It is activated when a person swipes it through the subway turnstile.

See Mishna, Gittin 1:5, translated in Artscroll, supra note 1. 
admissible in a Jewish court. In fact, Rabbi Spektor held that "one can rely upon the official testimony of the courts more than upon the words of one witness." 124 In one case decided by Spektor, a man had been conscripted into the army fourteen years before and had not been heard from for three years. ${ }^{125}$ Military and civil authorities in the city conducted an investigation and released an official document signed by governmental authorities and police stating that he had died in a hospital of a serious illness. Citing the talmudic principle related above, Spektor accepted the government's document as conclusive evidence of the man's death. In another case presided over by Spektor, hearsay evidence coupled with an official letter from the military confirming a death were found conclusive in establishing a man's demise. ${ }^{126}$ Spektor reasons that the military investigates such cases carefully before reporting a death because of the potential embarrassment that would arise if it later became known, through a prisoner exchange, for example, that a soldier was not killed but instead was taken captive. ${ }^{127}$ If he had not been killed, but instead was taken captive, and there was an exchange of prisoners, it would have been found out that they had lied.

In the case of the Trade Center deaths, the city's death certificates may be as reliable as the death certifications mentioned above. The Trade Center death affidavit forms require explicit information regarding the whereabouts of missing persons, including evidence of any contact on the morning of 11 September, such as telephone calls and e-mails, as well as efforts taken by the family to locate the person. ${ }^{128}$ On the other hand, the informational website regarding the death certificates maintains that they can be obtained "in many, but not all cases within a week or two after family members apply for them." 129 Claims like this one suggest that in its eagerness to grant death certificates to grieving, financially burdened families, the city may not actually investigate people's claims thoroughly. This is supported by the large number of death certificates that were in fact awarded in a short period of time. ${ }^{130}$ Thoroughness is imperative in order that any certificates have probative value in a rabbinical court. Thus, it is conceivable that rabbis may elect not to admit the city's death certificates in their considerations of missing person cases.

Y.E. Spektor, Ein Yitzchak, Even Haezer $\$ 19$ translated in S.B. Freehof, The Responsa Literature and $A$ Treasury of Responsa (1973) at 290 [hereinafter Spektor].

12s See Rakeffet-Rothkoff, supra note 109 at 15.

126 See Rakeffet-Rothkoff, ibid. at 16.

127 See Spektor, supra note 124 at 291.

128 WTC Death Affidavit Forms/Information available online: <www.nyc.gov/html/em/dth_cert.html> (date accessed: 25 March 2002).

lbid.

130 As of 18 January 2002, out of a total official estimate of 3,113 dead or missing and presumed dead, The New York Times reported that 670 death certificates were issued by the medical examiner's office and 1,952 death certificates were issued at the request of families. See The New York Times (21 January 2002) A9. 


\section{INSURANCE SCAMS}

In deciding agunah cases, in order to confirm that a spouse is in fact dead, rabbis have traditionally considered what missing spouses might have to gain by their absence - that is, what would be their incentive to flee? Rabbis early on considered the possibility that people might file false Trade Center death claims for the purpose of collecting charity or insurance. ${ }^{131}$ Their fears seemed confirmed when it was publicized in the months following the attack that such fraud had in fact transpired throughout the country. Currently, a Georgia couple and a New Orleans woman are facing charges of insurance fraud for filing false Trade Center death claims. ${ }^{132}$ Others have been arrested while attempting to fraudulently procure death certificates undoubtedly to file fraudulent claims. ${ }^{133}$ One defrauder, who spun tales of loss and bereavement that prompted many to give him handouts, was recently exposed in a local paper. ${ }^{134}$ Insurance companies' present generous policy of "pay now and ask questions later" has perhaps encouraged such schemes.

Despite the existence of fraudulent practices, it is unlikely that such concerns will hinder the conferral of rabbinic dispensations to declare a person missing in the Trade Center dead. First, insurance scams are being carefully investigated. ${ }^{135}$ Second, in assessing the merits of each case, extensive investigations are conducted by a group of rabbis. The rabbis question witnesses, hear testimony and gather evidence. No case is decided without a thorough examination of phone records, e-mails and faxes. ${ }^{136}$ It seems extremely unlikely that a fraudulent claim would pass muster under thorough investigation. Last, there is a talmudic principle that a woman is careful before remarrying. ${ }^{137} \mathrm{~A}$ woman is unlikely to try to remarry if she knows that she is still married to her husband. ${ }^{138}$ In light of these considerations, the chance of a rabbinic panel ruling affirmatively on a fraudulent case seems remote. Thus, there is little reason for concern that a rabbinic agunah ruling will be based on a fraudulent claim.

\section{CONClusion}

Since 11 September, panels of rabbis have examined many tragic situations in order to determine the status of missing persons. Families consulted rabbis while still in the midst of traumatic ordeals, fearing the loss of people beloved to them. Pregnant women, already grieving for missing husbands and apprehensive of an agonizing future, asked the rabbis for guidance. ${ }^{139}$ People turned to rabbinic authorities for permission to

See Willig, supra note 57. See also G. Wilson, "Insurers are on Alert For Phony Claims" New York Daily News (3 December 2001) 31 [hereinafter Wilson].

Insurance administrators predict that these are just the beginning of bogus claims that will be filed in the wake of the 11 September attacks. See Wilson, ibid. at 31.

Ibid.

See N. Coleman. "Knowing my Place" St. Paul Pioneer Press (26 January 2002) Al.

See Wilson, supra note 131 at 31 .

See Willig, supra note 57.

See Babylonian Talmud, Yebamot 25a, translated in Soncino, supra note 1.

Ibid.

See Reiss, supra note 121. 
begin a formal mourning process that would help them to grapple with their feelings of bereavement and pain. The rabbis had the onerous task of applying the law and ruling on each individual case with compassion and sensitivity to each bereaved family that came to them.

Rabbis made a tremendous effort to establish that missing people had in fact perished in the Trade Center so that families could begin to mourn. No stone was left unturned in their searches for clues as to why and how a missing person could have died. In each case discussed by the rabbis in public fora held on the topic, they detailed the considerations that allowed them to permit women to mourn and eventually remarry. In view of the precedent established by cases in which women were permitted to remarry when far less probative evidence was available, and the level of sensitivity and heavy responsibility with which the rabbis approached their task, it is quite probable that a dispensation has been given or will be given in each Trade Center death case. Therefore, based on halakhah and case precedent, the World Trade Center tragedy will not give rise to an agunah crisis. Thus, in their time of suffering and loss, women can feel reassured that they are relieved of the extra burden of facing an agunah catastrophe. 